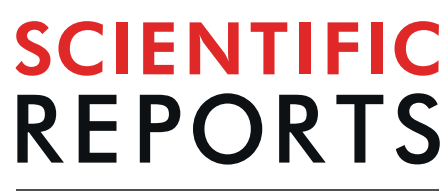

natureresearch

\title{
OPEN Author Correction: Biofilm formation by multidrug resistant Enterobacteriaceae strains isolated from solid organ transplant recipients
}

\begin{abstract}
José Ramos-Vivas, Itziar Chapartegui-González, Marta Fernández-Martínez, Claudia González-Rico, Jesús Fortún, Rosa Escudero, Francesc Marco, Laura Linares, Miguel Montejo, Maitane Aranzamendi, Patricia Muñoz, Maricela Valerio, Jose María Aguado, Elena Resino, Irene Gracia Ahufinger, Aurora Paz Vega, Luis Martínez-Martínez, María Carmen Fariñas, \& The ENTHERE Study Group, the Group for Study of Infection in Transplantation of the Spanish Society of Infectious Diseases and Clinical Microbiology (GESITRA-SEIMC) and the Spanish Network for Research in Infectious Diseases (REIPI) ${ }^{\dagger}$
\end{abstract}

Correction to: Scientific Reports https://doi.org/10.1038/s41598-019-45060-y, published online 20 June 2019

The original version of this Article contained a typographical error in the spelling of the author Luis Martínez-Martínez, which was incorrectly given as Luis Martínez.

In addition, this Article contained a typographical error in the following affiliation.

Infectiuos Diseases Unit, Hospital Universitario Cruces, Plaza de Cruces, S/N, 48903, Baracaldo, Vizcaya,Spain now reads:

Infectious Diseases Unit, Hospital Universitario Cruces, Plaza de Cruces, S/N, 48903, Baracaldo, Vizcaya, Spain These errors have now been corrected in the PDF and HTML versions of the Article, and in the accompanying Supplementary Material File.

\begin{abstract}
(c) (i) Open Access This article is licensed under a Creative Commons Attribution 4.0 International License, which permits use, sharing, adaptation, distribution and reproduction in any medium or format, as long as you give appropriate credit to the original author(s) and the source, provide a link to the Creative Commons license, and indicate if changes were made. The images or other third party material in this article are included in the article's Creative Commons license, unless indicated otherwise in a credit line to the material. If material is not included in the article's Creative Commons license and your intended use is not permitted by statutory regulation or exceeds the permitted use, you will need to obtain permission directly from the copyright holder. To view a copy of this license, visit http://creativecommons.org/licenses/by/4.0/.
\end{abstract}

(C) The Author(s) 2020 


\section{Consortia}

The ENTHERE Study Group, the Group for Study of Infection in Transplantation of the Spanish Society of Infectious Diseases and Clinical Microbiology (GESITRASEIMC) and the Spanish Network for Research in Infectious Diseases (REIPI)

Juan Carlos Ruiz San Millán, Emilio Rodrigo, Fernando Casafont Morencos, Emilio Fabrega, Antonio Cuadrado, Concepción Fariñas-Alvarez, Mónica Gozalo, Francisco Arnaíz de las Revillas, Pilar Martín Dávila, Adolfo Martínez, Patricia Ruíz Garbajosa, Asunción Moreno, Marta Bodro, María Fernanda Solano, María José Blanco, Javier Nieto, Marina Machado, María Olmedo, Sara Rodríguez Fernández, Cristina Rincón Sanz, Teresa Vicente Rangel, Caroline Agnelli Bento, Alicia Galar Recalde, Alia Eworo, Fernando Anaya Fernández-Lomana, María Luisa Rodríguez-Ferrero, Luis Alberto Sánchez Cámara, Fernando Chaves \& Julián de la Torre Cisneros 